\title{
THE MEDITERRANEAN \\ IN AN AGE OF GLOBALISATION
}

\author{
Fred Halliday
}

$2008 / 17$

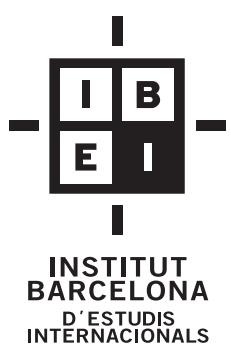

Fred Halliday

Fred Halliday is ICREA Research Professor at the Institut Barcelona d'Estudis Internacionals (IBEI). ICREA, Catalan Institution for Research and Advanced Studies, is a foundation jointly promoted by the Catalan Government through the Ministry of Innovation, Universities and Enterprise, and the Catalan Foundation for Research and Innovation (FCRI).

fhalliday@ibei.org 
IBEI WORKING PAPERS

2008/17

The Mediterranean in an Age of Globalisation

\author{
(c) Fred Halliday \\ (c) IBEI, de esta edición \\ Edita: CIDOB edicions \\ Elisabets, 12 \\ 08001 Barcelona \\ Tel. 933026495 \\ Fax. 933022118 \\ E-mail: publicaciones@cidob.org \\ URL: www.cidob.org
}

Depósito legal: B-21.147-2006

ISSN:1886-2802

Imprime: Color Marfil, S.L.

Barcelona, December 2008 


\section{Introduction}

I would like to start with some obvious, but I think important, observations about how we as academic analysts, in this case students of politics and international relations, define our priorities and our relation to the world in which we live. First of all, we should recognise that in the work we do, and the research we deem to be significant, we operate in a multiple context, one of at least three concentric circles. All science, all IR, indeed all social science involves an intersection, a necessary and never resolved, but creative, tension between the theories and specific concerns of the discipline and the broader context in which we live, be it that of the social scientific and intellectual climate of the time, or that of what we, somewhat defensively, term the 'real world', that of events and historic changes that, in one way or another, impact on what we do. Indeed in my introductory theory lectures at LSE for years, trying to counter, on the one hand, a preoccupation with current events alone, or, on the other hand, a focus on theory, a theoreticism, that ignored broader challenges and contexts, I urged students to look at the development of the discipline, and indeed the contexts and preoccupations of a conference such as yours, in terms of the three determinant circles: the discipline itself and its evolution; the broader context of ideas in social science and contemporary thought in general; and the development of the world, no more 'real' than that of ideas, or theories, but important none the less, of politics, events, crises².

So much for particular issues. I hope I have said enough to illustrate the ways in which, through creative interaction and tension, broad concerns in social science, and in contemporary academic and intellectual debate, may interact with a particular region.

Here I would recall a particular, poignant, episode some years ago, which I shared with our chairman of today, Michael Cox. The last time that I spoke at an ECPR Conference was some years ago, when the main ECPR Conference was held in Britain, in the ancient cathedral and pilgrimage city of Canterbury, a sort of English equivalent of Santiago de Compostela in Spain. Working as I was at the time on a book on the IR of the Middle East, which later saw the light of day with CUP in 2005, I gave a paper on the role of ideologies in the contemporary Middle East. It was, as ever a lively event, and I met many old friends and made some news ones. The next I returned by train to London, in the company of my good friend, now your president, Professor Michael Cox. As the train passed in early autumn sunlight over the river Deal and through the suburbs of London, Mick gave me a running commentary on what we were seeing, as this was where he had grown up, mi país, as they might say in Spain and I felt that, after a stimulating and reassuring ECPR conference, the coming months with attendant research and teaching were well under control. The date

\footnotetext{
This paper reflects the contents of the Plenary Lecture addressed to the participants of the $2^{\text {nd }}$ Graduate Conference, European Consortium for Political Science, Universitat Autonòma de Barcelona, 25 August 2008

See my Rethinking Internacional Relations, London: Macmillan, 1994, Spanish edition Les Relaciones Internacionales en un mundo en transición, foreward by Celestino del Arenal, Madrid: Catarata, 2002.
} 
of this train journey was, however, 10 September 2001: the next day, at some point in the early afternoon, the phone rang, it was my son from school and I did not believe him, with news of the New York events. For all our theories, and quantifications, and predictions, and models, and, indeed for all our historical insights, we should never forget the ability of people, and events, not to mention restless or incompetent states, to surprise us. Herein lies, of course, another, never that remote, challenge to the work that we do. It is not, it has to be emphasised, our task to predict such events, but it is our responsibility, in retrospect, to explain them, and, I would argue, with the combination of theoretical, historical, country-specific and, not least, moral skills that we have, this is something we can do.

In my own work I have tried in this way to engage, in a way that welcomes the tension of ideas with the outside world, with some major events or regions in the world: with the Middle East, with the Cold War, with the phenomenon of revolutions in world affairs, with the role of culture, with that of gender. And in this regard my lecture today is an attempt, much of it covering ground that is familiar, but born of a personal interaction over the past few years, to lay out some thoughts about how, living and working in a city that is on the shores of the Mediterranean, and which is affected by many of the trends prevailing in this region, such an engagement may be reflected in the broader concerns of contemporary thinking on IR and political science.

Secondly, I am conscious of, and happy to associate myself with, the rubric of the organisation that is hosting us here today, that of a 'European Consortium'. By 'Consortium' I understand a group of institutions, cultures, programmes working together without seeking to impose on theory, methodology, research agenda. By 'European' I understand all of the 27 countries that now comprise the EU as well as others who are associated with, and who aspire to participate in, its workings as a democratic, peaceful and prosperous entity. From these two terms flow, in my view, a number of conclusions. First, that, while we engage with, study, respect, learn from the theoretical and disciplinary contributions of other continents and academic cultures, be they those of the USA or of the non-western world, we have, and should defend and develop, a set of intellectual values that are specifically European, in origin, engagement and formulation. Among these I would mention the linking of work in political science and IR to the central concerns of Europe today, namely peace, human rights and democracy, in broad terms the contemporary reformulation and reaffirmation of the values that underlay the European Enlightenment of two centuries ago. We not so concerned, and should be sceptical towards, on the one hand the concern, when not obsession, with hegemony, unipolarity, world order and the like which emanates from the other side of the Atlantic. At the same time and while informing ourselves of the concerns, and cultures, of the non-western world, most immediately that of our Middle Eastern neighbours, we should not allow a support for pluralism and diversity, and a justified revulsion at the past crimes of European colonialism, not least massacres committed in this Mediterranean, to undermine our commitment to universality, individual liberties, equality and, something for which our forebears fought for many centuries and which we abandon or dilute at our peril, secularism. 
As Europeans, we should, moreover, defend, and, in my view, be much more robust about, certain elements of the European intellectual tradition that are today somewhat sidelined in social, including political, science: a recognition of the importance of history in shaping the contemporary world, and of the need to study history, of peoples, states, economies, also of ideas, as part of the formation of any educated individual or discipline; secondly, a respect for, and commitment to, a plurality of languages and, indeed, to the study of language as a necessary part of any educated and political responsible person; thirdly, while maintaining a commitment to separating analytic from ethical or normative concerns, to maintain at the centre of what we research and write about an awareness of the necessary link between social science and ethical issues, and of the responsibility of social science to address major problems and issues of our times; finally, an awareness of place, of local, national and regional difference, and of the need to educate students, and a broader public, even as we aspire to understand the 'global', also to maintain a relationship with, and an informed understanding of, the societies and regions in which we live.

In this regard, and bearing in mind the location of this conference, and this city, in the Mediterranean it is pertinent to recall some of the great thinkers who have emerged from these societies and engaged with this region in the past. Here I would mention three. First, the greatest medieval comparative historian and political sociologists, born in 1332 from a family of merchants and courtiers recently expelled from Seville by the reconquista, who died in Tunis in 1406, Ibn Khaldun, whose major work, the Muqaddimah, or 'Prologues', is a commanding study of the rise and fall of states, of the intersection of war and politics, of the role and decay of social solidarity, and of the intersection of nomadic and settled societies across North Africa. Secondly, the Italian Hegelian and Marxist Antonio Gramsci, author of The Modern Prince, itself a reference back to the work of another great sixteenth century thinker of this region, Niccolò Machiavelli, and several volumes of Prison Notebooks born in the town of Ales, Sardinia in 1891 and died a week after being released from Mussolini's jail in 1937: like Ibn Khaldun, and indeed like Macchiavelli, Gramsci was preoccupied with central themes in politics and historical sociology: the rise and consolidation of states, with the role of ideology and legitimacy in consolidating states, with the relative roles of coercion and consent in maintaining political systems, and with the conditions under which alternative political and social forces, capable of challenging these orders, could emerge. Thirdly, the French historian and founder of the Annales school, Fernand Braudel, whose great work, published in two volumes in French in 1949 and in English in 1972, The Mediterranean and the Mediterranean World in the Age of Philip II, provides a commanding overview of this region as a whole, of the forces, long-term, conjunctural and immediate, that shaped it, and of the manner in which, in the second half of the sixteenth century as much as in the first part of the twenty-first, the countries of the Mediterranean interact and engage as much with the world beyond, to the east, north and west, as they do with each other.

This lecture is, in some measure, a tribute to the work of Braudel, beginning with the title, 'in an Age of Globalisation', a formulation I intend to convey recognition of how in earlier times, that of the Phoenician and Roman empires, that of 
the early modern Europe of Braudel's study, in that of the European empires of the nineteenth and twentieth centuries, as well as in World War and Cold War, the fate of the Mediterranean, be it in security, economic or political terms was intricately linked to the wider world. By recalling Braudel's work we may also set our own research, when not our own age, in a somewhat more modest light: for few social scientists or historians today can display the intellectual imagination, or the command of languages and sources, let alone the analytic insights, of which Braudel's work is an exemplar. As for the times, suffice it to say it is rather more uplifting to promote the study of the Mediterranean in the age of Philip II, or of Napoleon, of Garibaldi or of Atatúrk, than in that of Silvio Berlusconi.

\section{The Role of History}

To stress the role of history, as I have done in the introduction to this lecture, not to argue that history, conceived as a unity narrative, explains the present, but rather to allow us to separate real, from imagined, or invented, historical causes, and also, in the spirit of public, political, debate, as much as in academic research, to emancipate ourselves, through critical reflection, from the imposition of historical myths.

Much is made in the study, and in the diplomatic and cultural rhetoric, of the Mediterranean about the role of history, in regard to two claims in particular, One is that of Mare Nostrum, Latin for 'Our Sea', the idea from which the relatively recent, early nineteenth century, concept of the 'Mediterranean' as a regional entity is derived. From this follows much rhetoric about the cultural legacy, of diversity, interaction and tolerance, that may be derived from this history and put to contemporary use. At times of major international conferences, such as those in Barcelona in 1995 and 2005, or at the recent Union of the Mediterranean summit in Paris, to which President Sarkozy invited all EU and Mediterranean states, the same paradigm, of a historical bedrock that may serve today's needs, was much in evidence.

This is, however, an instrumental, and in many ways, inaccurate picture of the region's past and, it may be argued, as little of promise for resolving the problems of today. First, because as much as there are, and were, forms of cultural, economic, and, not least, gastronomic, interaction in the Mediterranean, its history is much more one of conflict, rivalry, fragmentation, than that of some supposed unity. Those who lament the end of Christian unity in the third century AD, or the rise of Islam in the seventh century, or the more recent spread of nationalism, presume a unity that was rarely there. Braudel's own work focuses, in its third, political, part on the division of the Mediterranean, between an Ottoman Empire that looks increasingly east, to Persia and Central Asia, and a Spanish empire, that of Philip II and his successors, who look to the new colonies in the Americas. To this may be added the observation, strongly advocated by two recent writers, Professor Pere Vilanova of 
the University of Barcelona, and the former Le Monde correspondent, himself originally from Lebanon, Paul Balta, according to which the very concept of a unitary Mediterranean has, in political, security and economic terms, but ceased to exist ${ }^{3}$, even as, hopefully, it survives in its environmental and gastronomic dimensions. . Once modern communications systems were opened up in the early part of the nineteenth century, the countries of the Mediterranean conducted more and more of their trade with the rest of the world by land, not sea, routes and became more and more integrated into the hinterland economies, be they of Europe or the Middle East, onto which they abutted. Balta, indeed, argues that today we are dealing not with one, but with six Mediterraneans, encompassing the EU democracies on the west, the Balkans, Turkey, the Arab East, Israel and North Africa.

This brief, and non-deterministic, account of history provides an entry into the second issue I want to address, namely that of states and state formation, and, in particular, the question of how this map of states came about, and what the formative historical forces determining the outcome were. There are now, with the independence of Montenegro, 24 independent political entities bordering the Mediterranean, and, if we include Monaco, the Vatican and Palestine in the total, 27. All of these states claim ancient origins, and seek to derive legitimacy from this, in such a way that the general mystificatory use of a supposedly historic Mediterranean region is reinforced, albeit in an often antagonistic and self-regarding way, by the claims to historic identity and ancestral roots of the individual peoples.

A brisk, and unflinching, application of the historical sociological knife may, however, tell a different story. First, for all of the talk of ancient peoples, times, and so forth, no state in the Mediterranean is more than five hundred years, half a millennium, old, and none has any plausible derivation from, or continuous association with, the historic or ancient states from which many claim legitimacy or descent. Rather, what we see is the emergence, or rather forcible, coercive, bloody and contingent, creation of blocs of states over the past centuries, above all as a result of four formative phases: dynastic state formation in the sixteenth century, which produced Spain, France, Turkey; colonial occupation and delineation in the nineteenth and early twentieth centuries, out of which emerged the map of Arab states from Syria to Morocco, together with Malta and Cyprus; nationalist upheaval in the same period, from which Italy, Serbia, Albania and Greece emerged; and inter-ethnic conflict in the twentieth, shaping the Balkans and Israel. Whatever else, there is little that is ancient, cultural, 'natural', let alone 'God-given' in this outcome. Military power, be it internally generated or imposed, as with colonialism, from without, was the dominant factor.

3. Pere Vilanova, 'What if the Mediterranean would not or does not exist? Exploring heterodox hypothesis' Paper presented at the Fourth Mediterranean Social and Political Research Meeting, Florence \& Montecatini Terme 19 - 23 March 2003, organised by the Mediterranean Programme of the Robert Schuman Centre for Advanced Studies at the European University Institute; Paul Balta, Euroediterráneo: Desafís y Propuestas, Madrid: Oriente y Mediterraneo, 2005. 


\section{The Mediterranean Today}

Against this background, and with these, for sure not attainable, intellectual aspirations, let me discuss some themes which are, or in my view should be, central to the general debates on IR and on globalisation, which are exemplified by contemporary trends in the Mediterranean region, and which have been very much brought to my attention by living and working in this environment over the past four years. First let me mention themes which, while present in the globalisation literature we produce and use in teaching across Europe, and elsewhere. Then, let me discuss some broader questions that are raised by the Mediterranean experience and context. Of contemporary, when not immediate, themes, ones raised by the encounter of a metropolitan professor of IR with the reality of the Catalonia and Spain of to-day, I would selected five.

\subsection{The Enduring Autonomy of States}

We are, first of all, whether students of politics or of IR, students of states, and of what they can, and cannot, do, within the constraints under which they find themselves. It is therefore fitting to say something about Spain in the context of European and Mediterranean politics and society. In its internal political and social change, rapid in some ways and remarkably stable in others, Spain is, with, arguably Russia, Germany and Turkey, one of the most fast changing and interesting countries in Europe today. For anyone interested in the changing role of the state in society and economy, in the impact of globalisation on industry, the media, the banking system, on the impact of migration, really a matter of the past decade alone, on society, on shifting patterns of behaviour, attitude, culture, not least language, between generations, then Spain in general, and Catalonia in particular, are a laboratory, a field of experimentation and unpredictability, enough to command the attention of any social scientist, as well as anyone interested in the stuff of human experience and aspiration.

The main theme I want to underlie is that for all that we talk of, and recognise, the impact of globalisation, states, in their autonomy and distinct interests, still retain and important role. To take the case of Spain. This is, first of all, a country which has come to democracy, to prosperity, to changed attitudes towards gender, to an international financial and cultural role, within the last generation, since, in effect, the transition to democracy in the late 1970s. This is a country where, on the one hand, and according to opinion polls conducted in 2006, on the seventieth anniversary of the start of the civil war, almost a third of people, including any young people, approve of the late dictator, General Franco, and yet where a socialist government, twice elected, in 2004 and in 2009, has produced a cabinet in which half of the ministers are women, in which gay marriage is supported, in which divorce, by consent, is within a matter of months. 
My one serious difficulty with my Spanish and Catalan colleagues is that they are not proud, and vocal, enough about the things they have achieved. For all the modesty of the Spanish about their own achievements, you have in a city like Barcelona cultural centres, a musical life, bookshops that would be the envy of any other city, and you have still in Spain, for how long I cannot say, a serious newspaper culture that does not demean its readers with gossip and with drivel, as is the case in Britain and elsewhere. For all the repetitiveness and intermittent parochialism of public debate on issues of Catalan autonomy and national rights, you have in everyday life in a city like Barcelona a level of lived, everyday existing, bilingualism, and mutual tolerance, that are almost unique in the world.

In international affairs, Spain has a record second to one in support of international understanding and the maintenance of peace, in seeking to encompass debate on terrorism, of which it has more direct experience than most, within a debate on democratic values and the defence of the rule of law, in backing for the European Constitution, and in resistance to the more egregious regressions in social policy, be it on the working week, on gender, or on immigration, emanating from the European parliament or from fellow EU states, in eastern Europe or, more immediately, across the Tyrrenian Sea.

In a word, against all the pressures for conformity within the EU, NATO and the west, against all our emphasis as students of politics and international affairs on structures and determinant factors, Spain has, in recent years, shown an admirable originality, independence, and commitment to democratic values that few other countries can equal. After the March 2004 bombings in Madrid, in which 193 people died, many of them immigrants on their way to work on local trains, there was not a single anti-Arab, anti-Moroccan or anti-Muslim incident in this country. Spain's contribution to the European, and global, response to the rise of Islamist terrorism has been, on the one hand, and as is necessary, a heightened police and security vigilance, but on the other, an attempt to promote dialogue, understanding, on the basis of secular and universal values, with the states and societies of the Middle East, a response a million miles, in tone and culture, from the rhetoric of 'evil-doers', 'war against terror' and torture lite to which the USA has resorted. Spain has suffered, and for many years, the experience of terrorism, but there is no Spanish Guantanamo.

At the same time, the very autonomy of states that Spain has sought to put to good purpose serves to limit other processes that seek to bind the states and economies of these regions closer together and, not least, to lessen the very large income differentials which exist between the European and non-European states that border this sea. Perhaps the most dramatic economic fact, perhaps the most dramatic of international political economy, characterising this region is the persistence and indeed increase in massive income differentials between the northern and southern shores of the Mediterranean, rising from 15: 1 a decade or so ago, to perhaps 18:1 9 more today. The political consequences of this are that not only is the income and welfare gap rising, but everyone on the southern side, and way beyond the states bordering the Mediterranean and deep into Africa, knows this. The inequality, and the universal perception of it, are part of, not despite of, globalisation. And in a country like Spain, 
as in Italy, this inequality means that week after week boatloads of desperate people, many of them already dead or dying from dehydration and exposure, are found along the coasts and in neighbouring waters.

In the face of this trans-Mediterranean inequality, and of the evident long-term social and security implications which such inequality and unemployment entail, there has been much talk over recent decades of economic programmes for investment, trade, employment and education in the countries of the Mediterranean south. Such have been goals of the 1995 Barcelona process, as of the recent Union pour la Mediterranée (UPM) summit in Paris. Yet for a variety of reasons, the preference of investors, including Arab investors, to place their money elsewhere, in more secure and lucrative markets, and the reluctance of authoritarian states to yield economic control that is tied to their political power, such change has been slow, and, in any broader time frame, inadequate to meeting the challenges these states, and their EU interlocutors, face. With widespread under- and unemployment, inadequate education and training systems, and a massive population explosion, there is little to be complacent about in regard to this issue of welfare and prosperity that, more than any supposedly ancient faultlines, or cultural and religious difference, divides the Mediterranean.

The inadequacy, or competitiveness, of states is also evident in regard to issues of foreign policy and of security, topics that should receive a lecture in themselves. For all the talk of shared security, there is little or no multilateral cooperation or effective intervention in the Mediterranean. An exception are some of the states of Former Yugoslavia - Bosnia, Kosovo, Macedonia - where both NATO and the EU have played a role, at least to contain, if not to resolve, issues in disputes. Yet if we look at the wider region, we can identify at least five areas of conflict and uncertainty where no external power has any mediating or effective role, or, where it does, this power is not so much European, as American: thus we have, from west to east, Western Sahara, Palestine, Lebanon, Cyprus and Kurdistan. In the first four at least there is some sort of international role, usually adorned with the word 'process', while in the last, the war between the Turkish state and Kurdish rebels that has been conducted since 1984, and with close on 40,000 killed, there is none.

This endurance of conflict reflects in part something that from the top down we too rarely recognise, namely the intractability of local conflicts, and not least the reluctance, refusal, the opportunism, the bloody-mindedness, the meanness of spirit, of the parties involved: the current chairman of the EPRC, Professor Michael Cox, who has written extensively on the Irish question, or at least one of them, could tell us a thing or two about all that ${ }^{4}$. Recent events in Georgia, a conflict in which it would

4. Michael Cox, Adrian Guelke and Fiona Stephen eds, A farewell to arms? From 'long war' to long peace in Northern Ireland Manchester: Manchester University Press, 2000 
appear that there are no angels, have given us yet another, textbook, case of all this. At the same time, this failure to build regional institutions, and to resolve conflicts, reflects the continued vitality of inter-state differences. In Spain, for reasons of press interest and national policy, one often gets a different and revealing insight into the divergences of EU states themselves: the opposition of the Italians, loudly, and of the Spaniards, more quietly, to Germany's 2005 bid to join the UN Security Council; the Spanish refusal, born in part of concern for domestic implications, in Catalonia and the Basque country, to go with the EU and NATO majority on recognising the independence of Kosovo; the indignation of the Spanish Foreign Ministry at the conduct of the British delegation to the 2005 Barcelona review process, when last minute objections from Downing Street to the agreed compromise on Palestine, led the Egyptian president, and then all other Arab heads of state, to cancel their participation at the last moment; above all, the bitter, and enduring, disagreements over Iraq. The Spanish, as custodians of the EU's Barcelona Process, have also had some pertinent things to say about those who, without reference to, or acknowledgement of, Barcelona proceed to launch their own programmes, ill thought out in each case, for security and prosperity in the region - the Americans with their Middle East initiative in 2004, the French, with the UPM, more recently. That Madrid's own chairmanship of the OSCE for 2007 was somewhat deficient in attention and diplomatic investment, with negative consequences in both the South Caucasus and the Balkans, only underscores this point.

These inter-state differences among countries of the north are, of course, replicated in the south, and are evident in each of the give ongoing Mediterranean conflicts that I listed, as well, if in less muted form for the moment, in the Balkans. Thus in Western Sahara, Algeria and Morocco are at odds, in Palestine, not only is it a case of Israel and the Arabs, but of different Arab states, notably Syria and Egypt, having rival projects, in Lebanon, Syria and Israel have long stirred the pot, with the Lebanese doing plenty of stirring as well; in Cyprus, Greece and Turkey remain in rivalry. Only in Kurdistan is there no two-sided state conflict. Indeed, for students of non-state actors and conflict, the Kurdish case is interesting in that the external support for the PKK, with a few token inputs from supporters in Greece, and Armenia, and in earlier years episodic backing by Syria, comes from the Kurdish diaspora in western Europe, particularly Germany. At the same time, that a conflict of this magnitude, equal in human, moral and military scale, to the conflict between Israelis and Palestinians, should have endured for now 24 years without any significant external involvement, is itself remarkable, and scandalous, even if this accords, more or less, with the wishes of both parties involved.

Here we are in a world where globalisation, in the sense of the reduction of rivalries between states, and of conflict between societies, as well as in the sense of building stronger international and/or transnational institutions, has, yet had, little impact. In Istanbul, Beirut, Tel Aviv, there is indeed evidence of globalisation, in terms of tourism and, for some at least, life style: in Diyarbakir, the Bekaa Valley and Gaza, all this is rather less evident. And to these regional conflicts, we must also add, with consequences we cannot yet assess, the rise, in a number of southern Mediterranean states, of powerful and in some cases armed, Islamist groups: peaceful in Turkey, Egypt, Tunisia and, to 
a large degree, in Morocco, armed and with undeclared intentions and capabilities, in Lebanon, Palestine, Libya, and, most of all, Algeria. That Algiers, a capital city only five minutes more flying time from Barcelona than Madrid, has been the scene of repeated armed outrages in recent weeks, and in a country in whose civil war of the 1990s an estimated 150,000 people died, must give us pause and concern, first for the long-suffering people of Algeria, who experienced a previous terrible war against French colonial rule, and, secondly, for the region as a whole.

The implications of this for contemporary analysis are self-evident. First, for all the invocation of a common destiny or shared interests, these states, without exception, look to their national, state, interests, before those of the region as a whole. Small wonder, indeed, that the record of institution-building in the region is so low: the Barcelona Process, supposed to bring the EU and the southern states together, has achieved little or nothing, and the ill-prepared Sarkozy UPM initiative is likely to fare no better; the Arab states of North Africa, formally united in the Arab Maghrib Union, can agree on nothing and remain divided by bilateral conflicts - the King of Morocco even refusing to visit Paris for the UPM Summit in July because the President of Algeria was to be there. The most ambitious attempt to incorporate another state into the EU, that of the Turkish accession process, remains blocked, and is likely to fail. It is, indeed, one of the ironies of the history of this region in the past century, or more, that much of the responsibility for security has rested, or been appropriated, by states who do not border the waters of the Mediterranean, France and Turkey excepted: by the Austro-Hungarian empire prior to World War I, by Russia, before, during and since the Soviet period, by the most improbably interloper of all, the rather remote island state of Britain, and, for much of recent decades and for many states on the southern and eastern end of the Mediterranean still today, a state with no historic ties to this region and from the other side of the Atlantic, the United States.

This fragmentation of the region, and the primacy of state interests, has its corollary, an important one, in the cultural field. Much is made, in evocations of the classical past, in discussing the urban life of the major empires, and also in talking of the literary and cultural life of nineteenth and early twentieth century Mediterranean cities, of a cosmopolitanism that flourished around these shores. To evoke these pasts may serve a number of purposes, not least to counter myths of national, religious, ethnic homogeneity and enclosure. But such evocations need to be taken with some grains of reservation. First, for all the mixture of peoples, religious, languages, literatures and musics of the nineteenth and early twentieth centuries, in, say, Livorno, Venice, Salonika, Istanbul, Beirut, Alexandria, Algiers, or Tangiers, this model of cosmopolitanism was very different from that to which modern, liberal and individualist, society aspires: people were allocated to ethnic and religious communities, authority rested in established elder males, there was a clear hierarchy of power between different groups and, beneath the rush of languages, trade, diversity, not a little hatred and fear. Secondly, all of this, or nearly all of this, has been destroyed, and irrevocably so, by the history of the past century or so, by nationalist homogenisation, by the World and Cold Wars, and, more recently, by conflicts in Lebanon and the Balkans. Of the dozen or so cosmopolitan cities of a century ago, none, with the partial, 
and increasingly beleagured, exceptions of Istanbul and Beirut remain, and even cities of the Mediterranean interior, such as Sarajevo, Jerusalem and Cairo are losing, when they have not lost, their pluralistic character. Of new cosmopolitan cities in the Mediterranean produced by the globalisation and migration of recent years, Marseille and Barcelona, we may have some, moderate, expectations, but it is too early to say how stable, creative, or open the cosmopolitanism of such new cities, the Mediterranean equivalents of London, Berlin, Paris, Los Angeles will be. If the Italian model has any impact more widely, this does not serve as a good omen.

\subsection{Globalisation, Visible and Invisible}

My second theme is globalisation itself. First three obvious, but necessary, historical restorations of perspective. First, the need for scepticism, or at least clarity, when not fastidiousness, of criteria, with regard to the originality or specificity of the contemporary epoch: whatever is 'new' in contemporary globalisation, be it the rise in volumes of trade, the speed and minimal cost of transferring financial and other information, the role of the media, or the impact of migration, we are not dealing with phenomena that are completely novel, or without historical precedent, or comparative import. The second is that, much as we may be awe of the impact of globalisation, with its opening of minds, markets, societies, we must register massive failures of global co-ordination, by states and by private companies, in recent decades. This is most obviously the case with regard to the world energy market: nearly four decades on from the oil price rises of the early 1970s, when it was obvious to any sensible person with an eye to global price and political stability that inter-governmental regulation was needed, we remain, as recent events have shown so well, prisoners of price fluctuations, speculation, political risk and the sheer irrationality of a group of states, and distribution companies, holding the world to ransom, selling a product at ten times or more above its average cost per barrel. This is not an inevitable, or structural, failure, but a failure of political foresight and will, as it is of what we have, more recently, come to call global governance. The results are to be seen on every petrol station forecourt.

The Mediterranean has experienced not all, for sure, but in significant respects some of the phenomena which today characterise globalisation. You are all probably familiar enough with the general arguments on globalisation, with the division into different schools - for example, the taxonomy of David Held and his co-authors which divides the field into 'transformationalists',' hyperglobalists', and 'globalsceptics' - for me not to need to repeat the theoretical arguments here ${ }^{5}$. And, as is evident in any encounter of theory, or theoretical pluralism, with an empirical case, the raw

5. David Held, Anthony McGrew, David Goldblatt, Jonathan Perraton, Global Transformations Polity Press: Cambridge, 1999. 
facts, the empirical reality, of the Mediterranean today does not automatically resolve the debate in favour of one or other major theoretical framework: this region can provide support for all three theoretical approaches. Recent trends in transnational investment and asset acquisition, not least by sovereign wealth funds, might, and the vulnerability of European and Mediterranean economies to current trends in the world economy, the full import of which we are far from having fully in view, would support the hyperglobalists.

At the same time, Spain is being affected by the changes in the world economy that pose major challenges to it. The Spanish construction industry is undergoing a serious crisis, with activity down 25\%, the worst in Europe. Tourism in Spain as a whole is down over $8 \%$ this year, a drop over 620,000 people. Industry, in particular the textile industry, in Catalonia has been greatly and will continue to be even more affected by the rise in Chinese exports. These are what, in terms of Braudel's distinctions, would be the immediate, the events-based, or événementiel, changes. Yet, the ability of states, individually as in the case of Spain and other EU members, and collectively, via the European Development Bank, and other multilateral agencies, to mitigate and manage this crisis should not be underestimated: if it counted for nothing, there would not be the interest there is in the centrally fixed rate of interest, or in government bailout policies.

For all their theoretical abstraction, however, the paradigms of globalisation theory relate mainly to the present, to the immediate. There are, however, other, more longterm, ones that must equally claim attention. Let me here mention four, themes not normally combined in a single argument. One is the issue of the environment, whether, as some informed predictions have it, most of Barcelona and of the Spain's Mediterranean coast, will be either under sea water and/ or faced with major shortages of short water, by the end of this century, when not before: such longue duree processes were very much part, the first of the three major parts, and for more than three hundred pages, of Braudel's historical vision ${ }^{6}$ : indeed when once asked who, in his theory, were the agents or heroes of history, he is said to have answered 'estuaries' and 'forests'.

The second is the issue of gender, and of how changes associated with globalisation are affecting it, be it in the public realm, of employment, participation in political life, equality of opportunity and in the more private, if often publicly when not internationally shaped, world of family life, life choices, gender identity. The place of gender in the study of politics and international relations has been and remains contested, but I regard it as central and continue to propose, as I have done for 25 years, that there is no area of interstate or transnational relations, not war, not trade, not migration, not the internet, which is without a gender dimension ${ }^{7}$. I have yet to be proved wrong on this, though one day it may, in the best Poppe-

6. The Mediterranean and the Mediterranean World in the Age of Philip II vol. 1, pp. 25-352 Part One, 'The Role of the Environment'.

7. See Rethinking Internacional Relations Chapter 7 'Hidden From Internacional Relations: Women and the Internacional Arena'. 
rian fashion, occur. In brief here, I would only indicate a few, self-evident, areas in which gender is present in contemporary Mediterranean globalisation and politics: massive changes in patterns of female employment over the past generation, dramatic falls in some countries, including Spain, in birth rates; the central, when not alarmist, presence of issues of the headscarf or veil in debates on immigration and secularism in European and other societies, including Turkey; the ferocious and spiteful campaign conducted by the Vatican, and by the Spanish conference of bishops, COPE, on such questions as gay rights, secular education and the ordination of women priests, this only matched by the reassertion of religiously sanctioned patriarchy, disguised as tradition, in many Muslim countries, and, indeed, in Israel as well.

Two particular, and very divergent, areas where the presence of gender is understudied: one in the matter of terrorism, counter-terrorism etc., and the way in which, with the rise of new forms of armed violence and organisation, and the post-9/11 security policies in the west, above all in the USA, women, and what are generally thought of as women's values, have been pushed out of public life and public view, to be replaced by endless images of bearded, shouting, men with guns, on one side, and a new, clean-cut, and knuckle-brained, security culture on the other. One of the most dramatic, and least studied, aspects of the post-9/11 world is this re-masculinisation of public space, in east and west. The other area where gender plays a major, but usually unnoticed, role is in the transmission of migrant remittances. We are talking here of billions of dollars being sent every year, and rising every year, by migrants, in the case of Spain from North Africa and Latin America, back to their countries. But if we look more closely, and we only have anecdotal information to go on, we can ask to which institution this money is sent. The answer is not to banks, not to the state, not to the church, but, almost always, to the family, and, within the family, to women. In order words there has been a dramatic, hidden, feminisation of financial transfers that are larger than the foreign aid budget of western countries. In particular, and my anecdotal survey so far shows a $100 \%$ correlation, women migrants send money only to women. The men are not to be trusted. So it is mothers, grandmothers, sisters, aunts who receive the money, in a process the consequences of which we can guess at, but which have not, as yet, been properly studied.

Thirdly, let us not forget, as social scientists, that the primary form of human interaction, one that also serves to structure power, identity, and life in general, is not law, not economics, not politics, not sociology, but language. This is a theme which we are all daily aware of, but which Anglo-Saxon literature on globalisation and on international relations almost always ignores, monolingual as it is in approach and, more importantly, deaf and blind to the role of language in the contemporary world. I do not claim to have fully understood, to have gotten my head around, this question, but in everyday life in this city, where a working day involves encounter with, and at least passive understanding of, three languages - Catalan, Spanish and English - and where dozens of languages are spoken in the cafes, bars, schools of a new multi-ethnic community, it is constantly evident how language intersects with, and helps to structure, relations of power, wealth, language, access to technology, education, and, indeed, a wide gamut of leisure and interpersonal relations as well, at least until quite late into the night. At the same time, as is evident not so much in written 
but in spoken usage, globalisation, and processes associated with it, be they the internet, fashion, pop music, drugs culture, legal change, even, may I suggest, events in international relations, all affect the vocabulary and promote shifts of meaning in the languages being used. Spanish, for example, is now replete with apparently English words, but most of these do not mean in Spanish usage of today what they originally meant in English, and some, like bicing, footing, bulling, for cycling, jogging, and bullying, do not exist in English at all, nor so far as I know, does the dance known in colloquial Spanish as el maikhilyásson. The same applies the other way around: the English 'patio' does not correspond to its Spanish original, that of an enclosed inner courtyard, nor is Spanish 'cafetería' the same as English 'cafeteria', and so on. This broad subject, what I provisionally and somewhat grandiosely term 'the sociolinguistics of globalisation' awaits analysis but is, perhaps of all the themes I mention here, the one where the mainstream English-language literature on globalisation is most deficient.

If the sociolinguistics of globalisation remain a largely unexplored continent, this is equally so for another topic that, the fourth and perhaps most challenging, that I want to draw attention to here and which falls into the time frame that Braudel termed conjuncturel, in a rough English variant 'medium term'. This is the whole area of the submerged, unseen, criminal and undocumented side of globalisation, and of the flow of money, people, goods, licit and illicit, between countries. It is as, if our conventional studies of globalisation, regulations, world trade and the like, we look, as we only can with some accuracy, at what we can see, and measure, the bright side of the moon, but we ignore the other part, at least half, and possibly more, that is unseen. Some journalism, such as the recent work of Misha Glenny, and books on the mafia and related Italian groups, and a little academic literature, such as that of Moses Naïm and Michael Woodiwiss, does look at this, but it is a topic little registered in the mainstream literature, journals, conferences on globalisation and IPE, where all seems to be proceeding smoothly and licitly in world of regulation, transnationalisation and so on. ${ }^{8}$

I cannot, by the very nature of the issue at hand, give precise figures, but my sense, based on newspaper reporting, on court cases, on anecdotal material, on analyses of the dozens of other countries, well over half in the world, where no proper control of these things takes place, is that the conventional UN-derived figure for the percentage of world trade and finance, in broad terms movements of goods and services, which puts the figure at $15-20 \%$ is far too low. Let us take into account the fact that the second largest commodity traded in the world, narcotics, leaves no statistical trail. Let us take into account the large number of countries, including Russia

8. Misha Glenny, McMafia. Crime without Frontiers London: The Bodley Head, 2008; Peadar Kirby Vulnerability and Violence. The Impact of Globalisation, London: Pluto Press, 2006; Moses Naïm, Illicit. How Smugglers, Traffickers and Copycats are Hijacking the Global Economy, New York: Doubleday, 2005; Michael Woodiwiss, Gangster Capitalism. The United States and the Rise of Global Organized Crime London: Constable and Robinson, 2005; Transparency International Global Corruption Report, Cambridge University Press: annual. 
and much of the former Soviet Union, large parts of Africa, the Middle East and Latin America, where there are no statistics, no independent monitoring, no political controls on such matters. Where, above all, the hitherto existing state, authoritarian and inefficient as it was, did provide basic security, and social and economic goods: ask the Somalis, Iraqis, Afghans, and others.

Lest we blame all of this on peoples and cultures far away, let us not forget the contribution of old Europe to all of this. First and foremost, when we talk about illegal trade, be it in drugs, in capital, in women we must not look only at the supply side, but also at demand: it is our societies who, directly or indirectly, sustain and pay for this trade and who must bear responsibility for it.

In this vein, we must also recognise the existence, despite EU and OECD pressure over recent years, of several major zones of financial and fiscal irresponsibility, so-called 'tax havens, in Spanish more honestly paraisos fiscales, in Western Europe itself: Monaco, Lichtenstein, the Channel Islands, and, adjacent to where now are, and where the only official language is Catalan, the Pyrenean state of Andorra. To this we can add the role of other tax havens which, while outside the developed world, act in conjunction with, and with the protection of, our states - the Cayman Islands, Aruba and others in the Caribbean, Dubai in the Middle East. Nor does our, European and OECD, responsibility end here. No-one with the slightest acquaintance with the financial reporting of the past years can have failed to notice the large, and it seems rising, incidence of corruption, falsification of annual reports, accounting fraud, bribery and the like which are associated with corporate life in the USA and Europe, be it Enron, the subprime credit industry, Volkswagen, the Spanish coastal construction industry and its municipal allies. Of the legal immunity of the current prime minister of Italy I wish to say little, but there is a broader pattern, seen in perhaps every country in Europe except the Scandanavians, and which most certainly includes my country of origin, Ireland, and equally encompasses Spain, particularly in its regional and local forms, in which old, long-established, perhaps relatively low-key forms of evasion, complicity and corruption, have now, with the advent of new forms of technology and money management, with the infusion of large amounts of cash, with, in effect, a significant part of what globalisation brings in its train, acquired greatly enhanced capabilities and, one suspects, aspirations. With all the new money in the world, with an insatiable pull, on the demand side let us not forget, for drugs, with every day new forms of technological transfer and management, with the inability of established mechanisms to resist, or even monitor, such processes, my sense is that the ratio of visible to invisible, of legal to illegal, of licit to illicit, activity in the world of trade, and of finance, is moving steadily in favour of the latter. And this is a challenge for academic analysis, and for our understanding of trade, finance and regulation. 


\subsection{Ideologies}

Finally, I want to say something about ideas, and values, and their role in politics and international relations. It is remarkable how difficult our social sciences have found it to get a handle on the issue of how far ideas, be they collectively held such as nationalism or religion, or held by influential individuals, play a role in shaping events and history. We have the agent-structure debate, the ideational turn, the cultural this and that, no end of self-styled 'great debates', now constructivism, and no doubt more to come. Setting theory on one side, it would seem, from the briefest acquaintance with modern history and with the contemporary world, that, however we theorise it, ideas do indeed play a role in shaping states, peoples and events. People insist, through socialisation and education, in instilling them, and a lot of money is spent on this. States promote them, opposition movements promote rival ones. People, many people, are prepared to fight, die and, let us not forget, kill in their name. In studies of the functioning and stability of domestic political and social systems, as in those of smaller units such as families, religious communities, workplaces, and as Machiavelli and Gramsci above all reminded us, ideology, the belief in, or forced imposition of, a set of values is an essential part of the process. The recent work of the historical sociologist Michael Mann has emphasis the four-part structure of state power - ideological, economic, military and political ${ }^{9}$. In international relations, we have been more coy, recognising on some occasions the role of world-historical ideas, such as revolution, freedom or nationalism, in shaping events, but shying away from sustained engagement with this theme.

A disabused study of history may, however, assist in clarifying the other issue that besets, and bedevils, much contemporary public debate, not least on Turkish entry into the European Union, namely that of the supposed 'Clash of Civilisations' and, more specifically, the claim that in some way the Muslim world is historically antagonistic to Europe, and, in some supposedly substantive collective psychoanalytic sense, constitutes the European 'Other'. One may be permitted, first, for questioning whether, in any but the most metaphorical and imprecise of ways, nations, or states, have, or need, 'Others'. The very image is a false transposition from developmental child psychology to social and political analysis. If, however, we look at the actual record of Muslim states, specifically the Ottoman Empire, in European history, then what becomes evident is that there was no fixed pattern, that the Ottomans allied at various times with, and against, European powers, as the European powers did with each other, ending with the fateful decision of the Young Turks to side with Germany and Austria in World War I. As far as historical antagonisms and conflicts are concerned, Turkey was, at best, a secondary factor in the history of most European states: for Britain and France, Germany, Italy and Spain, and indeed for most countries in Eastern Europe sandwiched between Germany and Russia, it was other European

9. Michael Mann, The Sources of Social Power, vol. 1 Cambridge. Cambridge University Press, 1986 
states that were most important. The cultural 'Other', whether menacing or exotic, was for many European states the colonial world. As for Europe having 'Christian roots', and this linked to a claim that such 'roots' are monolithic, timeless, moral and cultural foundations, we need only recall, first, that Europe has quite other, secular, political and moral sources as well and that the political values that animate the countries of the EU today, as they do the states and protest movements of the southern shore of the Mediterranean, are products of modern politics, of nationalism, socialism, fascism. Above all our concept of democracy, a word that does not exist in the Bible, has ancient, secular, roots but has been given meaning by the social conflicts, revolutions and, not least, civil wars, of the past two centuries.

If we look at the Mediterranean in modern times, we can see it has been the arena for an amazing range of ideological experiments, of left and right, colonial, fascist, religious on one side, nationalist, reformist and revolutionary on the other. The Mediterranean has been a veritable lake of utopias: from the Italia Africana of Victor Emmanuel and Mussolini, Pax Britanica, Spain's war in the Rif, Algérie Française, more recently Pax Americana, all the aspirations of imperial powers, via the experiments with independent socialism in the Yugoslavia of Tito, the Albania of Enver Hoxha, the Arab socialisms of Nasser's Egypt, Qaddafi's Libya and the FLN's Algeria, through to the national-military aspirations of Kemalism in Turkey, of Zionism in Israel and, not to be forgotten, the Maltese socialism of Dom Mintoff. Now we seem to have drawn away from such visions, and must content ourselves with the more modest, perhaps more anodyne, aspirations of the Barcelona Process and Sarkozy's UPM.

Yet in one respect, and not least because of the failure of these other radical experiments, the issue of ideas, of ideological models, of values, is more important than ever. First, we need to set our own house in order, as Europeans, and recoup the ground we have lost in the face of Berlusconi and his like. The crisis of the European Constitution, and of the project more generally, is a crisis of authority and ideas, of 'hegemony', one Machiavelli and Gramsci would well have understood, not of economic integration, which is proceeding well, or of inter-state security, which is not, for the moment at least, in question. However, there is a much more important reason why we need to do this, in conjunction with other democratic states, to the east and to the west, if we can, namely that it is in Europe's values, and in the implementation of those values in public life, in politics, local and national, and in international affairs, that our greatest contribution to world peace and to greater understanding between peoples lies. Just as Western Europe prevailed over communism in Eastern Europe, after four decades of Cold War, and with an impact far greater than that of Ronald Reagan and his missiles, so our best contribution to the lessening of tensions with, and conflicts between, neighbouring states lies in our advocating, and remaining loyal to, our core values, of democracy, individualism, secularism and the rule of law. On this basis lies the possibility of improved relations between different Mediterranean countries and on the constitution, perhaps for the first time in history, of a community of states and societies around this sea. It is democracy, prosperity and human rights in the twenty-first century which will truly make this Mare Nostrum, not the invocation of semi-mythologised and, in the contemporary world, largely irrelevant models from the past. 


\section{The Centrality of Cities}

And here, let me conclude, with mention of a topic particularly underlined in my case by living and working in the wonderful city that is Barcelona, and which relates to the entities which are, more than nations, states, religions, classes, so-called 'civilisations' the primary source of reference for most of us in our working and social lives, namely cities. I have argued in this lecture and elsewhere against the temptations of explaining the present in terms of the past, in terms of asserting continuities or long histories to entities, such as nations, fault-lines or religions, that are then deemed to explain contemporary behaviour, be this 'the English character', the Spanish climate, or 'Islam'. But there is one institution, one human and political, creation that can indeed claim such historical antiquity and continuity, namely cities: in the Mediterranean these predate all the other forms of collective existence and in particular religions, nations or states, to which we conventionally refer. Indeed, at the risk of myself falling into primordialism or atavism, or misty-eyed verbiage about the Mediterranean, let me share with you a simple observation that, I believe is correct, and which occurred to me recently, which is that of all the several dozen cities that border this inland sea, urban areas of, say, over 250,000 people, only four, I repeat four, have been established since the fall of the Roman Empire in 410 AD. Almeria, by the Arabs in 995 AD, Valletta by the Knights of Malta in 1565, Livorno by the Medici in the sixteenth century, who transformed what had earlier been a fishing village into a free port in 1591, and Tel Aviv by Jewish settlers in $1909^{10}$. The contrast with, say, Africa, or the Americas, is striking indeed.

This should be enough to reduce us all to being weak-kneed primordialists, yet it need not: for cities are spaces, architectural and economic ensembles, more recently sites of airports and football clubs, that, like all human entities, change their nature over time, in the Mediterranean often change their names, religions, state location as well. And in this lies an important, modern, creative and potentially democratic lesson, namely that it is not the urban past, not the Roman walls, or the so-called 'Gothic' or 'Chinese' quarters, of Barcelona that determine their present, and our future, but our choices, consciously, rationally and democratically arrived at. Like languages, wine and food, our genetic inheritance as individuals we are free, if sufficiently educated and organised, to choose how to use this inheritance, for better, as in Barcelona, or for worse, as in some many cities of the north and east, where megalomaniac and philistine modernising rulers, and what in England are euphemistically termed 'the developers' so often hold sway.

No one who visits or lives here, least of all anyone used to the depradations, ugliness, lack of public responsibility and aesthetic sense of northern cities, can fail to be

10. I am most grateful to the Italian colleagues who, at the ECPR Conference itself, drew attention to Livorno, a city I had previously missed, as the fourth case. 
struck by the beauty, the order, the care, the civic responsibility evident in a city like this, or indeed in any of the smaller towns, and seaside resorts up and down the Costa Brava, to the north, and the Costa Dourada, to the south. For all the impact of illegal building sites and municipal scandals to which Spain, abetted by swarm of financial speculators from outside, Russian and British, has been subjected, one cannot help being struck by the care with which these urban areas are maintained, with their seaside walks, paseos maritimos, their open air and late night cafes and restaurants, their chiringuitos and fresh showers, as well as by the public squares, avenues, buildings of Barcelona, Girona, Tarragona and other towns. Equally, no one who walks around this city can fail to notice the wonderful markets, at once traditional and modernised, that dot the urban landscape, 'the lungs of a city' as one Barcelona paper recently termed them. Contrast this with the impoverished public space and inner urban areas of many cities in the UK and the USA, let alone with the monstrous images of urban modernity, markets, almost without living sentient people, that are being thrust upon us in images from Shanghai, Dubai, Kuala Lumpur, the bulldozed and clamped down Beijing of the Olympics, cities increasingly without decent public market, without bookshops, without a single aesthetic eccentricity or critical idea, cities without lungs, without civil society, in a word without soul.

This, urban life in its full and creative sense, is not merely a matter of administrative, of architecture, or what, in the demeaning English language phrase is termed 'local' government. It is not only of existential and economic importance to the more than $50 \%$ of the world's people who now live in cities, and an essential precondition for living a balanced, healthy, life, but also a cornerstone of democracy itself: without functioning urban institutions, without a lively and properly independent civil society, without the cultural life associated with it, with responsible and authoritative control, urban life becomes a jungle, oppressive, dysfunctional, polluted, stressed, inhuman. Indeed in all the literature on global governance, on the role of states, of civil society, of subsidiarity and the rest, this, perhaps the fundamental cornerstone of a global, human, world order is too easily forgotten. Here Europe, and European history, have a special responsibility, a responsibility of aesthetic, public health, cultural and democratic character, in setting an example, and nowhere more so than the admirable city in which we are now gathered. This too is something I have learnt, and greatly appreciated, from living and working here and something which, in its ramifications for politics and international relations, as much as for tourism, leisure, architecture, is something which can, and should, be of concern to us all. 